\title{
Pencegahan Terjadinya Tindak Pidana Nakotika pada Anak di Kelurahan Bantan Timur
}

\section{Prevention of Narcotics Crimes in Children in Bantan Timur Village}

\author{
M. Citra Ramadhan1), Marlina') \& Isnaini1)
}

1) Fakultas Hukum, Universitas Medan Area, Indonesia

2) Fakultas Hukum, Universitas Sumatera Utara, Indonesia

Diterima: 23 Januari 2020; Disetujui: 12 Maret 2020; Dipublish: 23 Maret 2020

*Coresponding Email: mcitraramadhan@gmail.com

\begin{abstract}
Abstrak
Perdagangan narkotika dewasa ini sangat mengkhwatirkan. Anak-anak yang notabene generasi penerus sebagai penentu kemajuan bangsa, terlibat dalam tindak pidana narkotika. Anak tidak hanya selaku penyalahguna, namun juga sebagai kurir dalam perdagangan narkotika. Hal ini tentu sangat memprihatikan, sehingga seluruh pemangku kepentingan (stake holder) harus berperan dalam melakukan pencegahan tindak pidana narkotika pada anak. Tindak Pidana narkotika mendapat ancaman pidana penjara dan denda yang berat. Inilah yang harus disadari oleh masayarakat, khususnya di daerah mitra, yaitu kelurahan Bantan Timur. Selain menyadarkan ancaman pidana, pendidikan hukum juga memberi tips agar anak tidak terlibat dalam tindak pidana narkotika, baik itu sebagai penyalahguna maupun kurir. Tentunya efektifitas dari tips pencegahan tersebut akan sangat ditetukan oleh lingkungan anak itu sendiri.
\end{abstract}

Kata Kunci: Pencegahan, Tindak Pidana Narkotika, Anak

\begin{abstract}
The narcotics trade today is very worrying. Children who are in fact the next generation as determining the progress of the nation, are involved in narcotics crime. Children are not only as abusers, but also as couriers in the narcotics trade. This is of course very concerned, so that all stakeholders (stakeholders) must play a role in preventing narcotics crime in children. Narcotics crime is threatened by imprisonment and heavy fines. This must be realized by the community, especially in partner areas, namely the Bantan Timur village. In addition to awareness of criminal threats, legal education also provides tips so that children are not involved in narcotics crime, both as abusers and couriers. Of course the effectiveness of these prevention tips will be determined by the child's environment itself.
\end{abstract}

Keywords: Prevention, Narcotics Crimes, Children

How to cite: Ramadhan, C.R., Marlina \& Isnaini (2020). Pencegahan Terjadinya Tindak Pidana Nakotika pada Anak Di Kelurahan Bantan Timur. Journal of Education, Humaniora and Social Sciences (JEHSS). 2 (3): $540-553$. 


\section{PENDAHULUAN}

Narkotika merupakan sebuah diksi yang terdengar berbahaya dan mencekam. Data yang diperoleh oleh Badan Narkotika Nasional (BNN), narkoba yang masuk ke Indonesia jumlahnya menembus hingga berton-ton dengan 72 jaringan aktif. Dalam 4 kasus terakhir di tahun 2017 yang ditangani BNN, para mafia narkoba sudah menggunakan senjata api pabrikan, bukan lagi rakitan seperti M16, Ak 47 dan Revolver (Ratna, 2017)

Permasalahan narkotika tidak ada hentinya untuk dibahas, karena dapat menimbulkan kerusakan fisik, mental, emosi maupun sikap dalam masyarakat (Makarao dkk, 2003). Ketergantungan narkoba disebabkan oleh penyalahgunaan zat yang disertai adanya toleransi zat (dosis semakin tinggi) berpengaruh pada fisik dan psikologis pemakainya (Eleanora, 2017). Akhir-akhir ini banyak bandar-bandar dan pengedar narkoba tertangkap dan mendapat sanksi berat, namun pelaku yang lain seperti tidak mengacuhkan bahkan lebih cenderung untuk memperluas daerah operasinya (Kaligis \& Associates. 2002). Korbannya bahkan termasuk anak-anak dan banyak dari generasi muda, baik itu sebagai pengguna maupun sebagai kurir.

Pada tataran regulasi, beberapan aturan hukum terkait permasalahan narkotika ini telah ada, bahkan diancam dengan sanksi pidana. Untuk itu, masyarakat harus diberikan pemahaman terkait agar terdapat ketaatan hokum (Nainggolan, M., Elvi Z., dan Saparuddin, 2010; Nainggolan, Zahara, dan Saparuddin, 2010). Ketaatan masyarakat terhadap hukum disebabkan tiga hal yakni: (1) takut berbuat dosa; (2) takut karena kekuasaan dari pihak penguasa berkaitan dengan sifat hukum yang bersifat imperatif; (3) takut karena malu berbuat jahat. Penegakan hukum dengan sarana non penal mempunyai sasaran dan tujuan untuk kepentingan internalisasi (Sunarso. 2004).

Penyimpangan tingkah laku atau perbuatan melanggar hukum yang dilakukan oleh anak disebabkan oleh berbagai faktor, antara lain adanya dampak negatif dari perkembangan informasi, arus globalisasi di bidang komunikasi dan informasi serta perubahan gaya dan cara hidup sebagian orang tua telah membawa perubahan sosial yang mendasar dalam kehidupan masyarakat yang sangat berpengaruh terhadap nilai dan prilaku dari seorang anak (Kusno, 2009).

Selain itu, anak yang kurang atau tidak memperoleh kasih sayang, asupan bimbingan dan pembinaan dalam pengembangan sikap, prilaku penyesuai diri serta pengawasan dari orang tua wali, atau orang tua asuh dan pergaulan lingkungan 
masyarakat yang kurang sehat juga menyebabkan seseorang anak dapat terjerumus dalam kejahatan (Kusno, 2009). Anak merupakan aset bangsa, rusaknya anak sebagai generasi muda akan menyebabkan rusaknya negara (Soedjono, 2000).

Berdasarkan faktor penyebab yang dipaparkan, maka yang perlu dilakukan dalam upaya pencegahan tindak pidana narkotika pada anak yang menjadi tanggung jawab semua pihak. Mengingat urgensi demikian, maka tim pengabdian kepada masyarakat Universitas Medan Area (UMA) terpanggil untuk ikut berperan serta dalam memberikan pendidikan hukum terkaiti pencegahan tindak pidana narkotika serta dampaknya di daerah mitra, dalam hal ini Kelurahan Bantan Timur.

Kelurahan Bantan Timur letaknya di Kecamatan Medan Tembung, Kota Medan, Propinsi Sumatera Utara, yang memiliki keragaman penduduk. Pada kelurahan ini pengetahuan dan pemahaman tentang hukum sangat kurang, perhatian terhadap lingkungan keluarga dan lingkungan sosial masih minim. Kondisi ini menyebabkan adanya anak-anak yang di khawatirkan berpotensi besar untuk terlibat dalam tindak pidana narkotika.

Metode pendekatan yang digunakan dalam kegiatan pengabdian pada masyarkat ini dalam bentuk pendidikan hukum tentang upaya penegakan hukum (law enforcement) preventif atau pencegahan terjadinya tindak pidana narkotika pada anak. Penyampaian dilakukan dengan menuntun peserta agar berperan aktif dalam mengikuti kegiatan berlangsung. Adapun penyampaian materi disampaikan dalam pembahasan berikut

\section{HASIL DAN PEMBAHASAN}

\section{Pengertian Narkotika}

Secara etimologi narkotika berasal dari bahasa Yunani, yaitu murke yang berarti terbius sehingga menjadi mati rasa atau tidak dapat merasakan apa-apa lagi. Pada bahasa Inggris, narcotic diartikan sebagai: a drug that dulls the sense, relives pain, induces sleep, and can produce addiction in varying degree (Soedarto, 1981). Menurut sistem hukum di Indonesia, penyalahgunaan narkotika dikualifikasikan kejahatan yang diatur dalam Undang-Undang No. 35 Tahun 2009 tentang Narkotika (UU Narkotika). Menurut UU ini, narkotika adalah zat atau obat yang berasal dari tanaman atau bukan dari tanaman, baik sintetis maupun semi sintetis yang dapat menyebabkan penurunan atau 
perubahan kesadaran, hilangnya rasa, mengurangi sampai menghilangkan rasa nyeri, dan dapat menimbulkan ketergantungan, pengolongannya diatur dalam UU dan keputusan Menteri Kesehatan (Undang-Undang Republik Indonesia No. 35 Tahun 2009).

\section{Kelompok Narkotik Alami}

Asian poppy (Papaver somniferum), Dikenal juga sebagai Opium atau Candu, yang sudah dibudidayakan sejak ribuan tahun yang lampau, untuk bahan obat-obatan. Terutama adalah buahnya yang masih muda, atau getah dari buahnya. Getah buah itu sebelum dikeringkan, berwarna putih, dan kental seperti susu, yang akan keluar dari buahnya, bila buah itu dipotong; dan getah itulah yang setelah dikeringkan, dikenal: Opium, atau Candu (madat). Opium, morfin dan heroin disebut obat berbahaya, karena pemakaian obat ini sfek atau pengaruh utamanya yang membahayakan, ialah bisa menimbulkan "ketagihan"; yang bila dipenuhi tuntutan "ketagihannya, akan terus pula menuntut dosis yang semakin lama semakin bertambah, hingga akhirnya membawa maut.

Marijuana, dikenal dengan nama medik Cannabis saliva. Marijuana berasal dari Meksiko, dan merupakan tumbuhan berumah dua, yakni pohon yang satu berbunga jantan, dan yang satunya lagi berbunga betina. Pada bunga betina, terdapat tudung bulubulu runcing, yang mengeluarkan sejenis damar atau resin, yang kemudian sering dikeringkan, untuk dijadikan ramuan untuk tembakau/rokok. Damar dan daun itulah yang bersifat psikologis aktif, atau mengandung zat narkotik aktif, terutama tetrahidrokanabirol, yang bisa memabukkan, yang di antaranya terdapat sejenis phenol (fenol) yang kemudian disebut: Cannabinot. Marijuana atau ganja, merupakan tumbuhan tahunan, yang mudah ditanam/tumbuh: tumbuhan itu di Turki dikenal dengan nama: Hashis. Di Maroko disebut: Kef, di India: Bhang, dan di Cina dinamakan: Ma. Karsonon (2004) dalam BNN (2005), mengatakan bahwa: 1) Ganja sering pula disebut cannabis dapat menimbulkan ketergantungan bagi pengguna, terutama ketergantungan mental yang diikuti kecanduan fisik dalam jangka lama. 2) Ganja mengandung zat kimia (delta-9-tetrahydrocannabinof) yang dapat mempengaruhi perasaan, penglihatan, dan pendengaran. 3) Dapat menimbulkan beberapa dampak, di antaranya: hilangnya konsentrasi, peningkatan denyut jantung, kehilangan keseimbangan dan koordinasi diri, rasa gelisah dan panik, depresi, kebingungan serta 
halusinasi. 4) Ganja dikenal pula dengan sebutan marijuana, gele, cimeng, hash, kangkung, oyen, ikat, bang, labang, grass, rumput, dan lain-lain.

Koka (Erythroxyton Cocae), dikenal berasal dari Amerika Selatan; daunnya mengandung zat kokaina (kokain/cokaine), yang bila sering dikonsumsi, dapat merusak paru-paru, dan juga melemahkan saraf otot (membuat tubuh menjadi lemah/lemas) bahkan bisa membuat tubuh menjadi lumpuh.

\section{Kelompok Narkotik Semisintetik/Sintetik}

Tentang morfin, yang bahan aktif utamanya diperoleh dari opium, dengan cara mengeringkan getah tanaman. Asian poppy, atau opium (candu), tidak akan diuraikan lagi, karena sudah Anda simak pada point tentang Asian Poppy. Dari Asian poppy atau opium juga diperoleh bahan narkotik lain, yaitu: Kodein.

Kodein, sampai saat sekarang ini dipakai/diperlukan untuk mengurangi rasa sakit, dan dalam takaran tertentu, dijadikan pula sebagai bahan untuk menambah khasiat obat batuk. Kodein, walau disebutkan tidak menimbulkan ketergantungan yang membahayakan, tetapi karena dibuat dari bahan yang sejenis dengan morfin, maka obat ini pun termasuk obat yang terlarang untuk dijualbelikan secara bebas/umum. Dan melalui proses kimia di dalam laboratorium, morfin bisa diproses lebih lanjut menjadi: Heroin.

Heroin, adalah jenis narkotik yang sejak dahulu paling banyak diperdagangkan secara illegal oleh sindikat narkoba; dan heroin kini lebih dikenal dengan nama: Putauw (terutama yang kini banyak diedarkan di Indonesia). Karsono (2004) mengatakan bahwa heroin, adalah 1) Jenis narkotik yang sangat keras dengan zat adiktif yang cukup tinggi dan bentuk beragam, di antaranya butiran, tepung, dan cairan. 2) Sifatnya memperdaya penggunanya dengan cepat baik secara fisik maupun mental. Sehingga usaha untuk mengurangi atau menghentikan pemakaiannya dapat menimbulkan rasa sakit disertai kejang-kejang, kram di perut disertai muntah-muntah, keluar ingus, mata berair, hilang nafsu makan, dan kehilangan cairan tubuh. 3) Salah satu jenis heroin yang sangat dikenal (populer) pada saat ini di kalangan pengguna adalah "putauw". Putauw merupakan jenis heroin dengan kadar lebih rendah (disebut dengan heroin kelas lima atau enam) berwarna putih. 4) Jenis heroin lainnya dikenal dengan berbagai nama, seperti etep, bedak, shiet, PT, dan putih. 
Putauw atau "pt", bekerjanya langsung dan menimbulkan ketergantungan lebih cepat dari narkotik atau obat-obatan psikotropik lainnya. Pt sering pula disebut: Bidadari Salju" dan banyak lagi istilah-istilah lainnya, terutama juga untuk tujuan mengaburkan/ menyamarkannya dari incaran pembersihan/ pemberantasan dari yang berwajib (polisi narkoba). Maka obat ini (putauw) dinyatakan terlarang Tidak boleh 1 dijual/beredar di seluruh wilayah Indonesia (BNN, 2005)

Narkotik sintetik, pada waktu Perang Dunia ke-2, telah dikembangkan narkotik yang seratus persen sintetik, yakni yang bersfiat sintetis, tidak diturunkan/dibuat langsung dari bahan alami, melainkan berdasarkan hasil tiruan/pengolahan manusia. Narkotik sintetik tersebut, di antaranya adalah 1) Methadone, 2) Meperindine (Demerol) dan, 3) Levorphanol. Ketiga obat-obatan itu, juga mempunyai efek analgesik (dapat mengurangi nyeri/rasa sakit), dan adiksi (kecanduan/ketergantungan secara fisik dan mental), yang sama seperti pada Narkotik alami. Dan dari ketiga sintetik itu, yang sekarang ini dipakai untuk menggantikan heroin, terutama mengurangi gejala ketagihan yang keras, dalam proses detoksifikasi Ipaighilangan pengaruh racun) pada diri korbankorban narkotik, adalah: Methadone. Tesapi ketiga obat-obatan tersebut di atas pun hanya dapat dibeli/diperoleh dengan sesep dokter. Atau bila benar-benar dibutuhkan untuk pengolahan/ penyembuhan bagi aecandu narkotik.

Obat-obat psikotropik, sebenarnya termasuk golongan non-narkotik, tetapi seperti halnya narkotik, obat-obat psikotropik juga mempunyai pengaruh atau efek-sampingan pada susunan saraf pusat. Sehingga meskipun efeknya tidak sekeras heroin, tetapi karena obat-obat psikotropik juga bisa menimbulkan ketergantungan fisik maupun psikologis/mental (adiktif), maka dianggap berbahaya; apalagi jika dipakai secara berlebihan, tanpa pantauan dokter.

\section{Obat Psikotropik Stimulans}

Untuk merangsang sistem saraf simpatik, yakni yang berfungsi untuk mengirim darah ke otak, jantung, paru dan sebagainya. Juga yang mempersiapkan seseorang untuk pengerahan tenaga jasmani; saraf-saraf dari daerah dada, dan pinggang. Dan dari saraf tulang belakang yang melewati ganglion, yakni simpul-simpul saraf yang berfungsi untuk bekerja pada organ-organ yang berlainan (BNN, 2005) 
Depresan, untuk menekan sistem saraf perasimpatik, yakni bagian dari saraf autonom, yang mendominasi sistem saraf simpatik, ketika seseorang sedang beristirahat, sistem saraf ini umumnya banyak mengurangi kegiatan yang dipicu oleh sistem saraf simpatik, dan mengurangi detak jantung. Tetapi senantiasa mengirim darah ke usus halus, dan meningkatkan pengeluaran getah pencernaan. Sistem saraf parasimpatik, sebagian berpusat di batang otak, dan daerah kelangkang atau sakrum, yaitu bagian dari tulang punggung (antara tulang-tulang pinggang dan tulang punggung yang terdiri atas lima ruas tulang yang menjadi satu), saraf tulang belakang; dan sebagian lagi bekerja pada organ-organ yang berlainan (BNN, 2005).

\section{Kelompok Stimulant}

Amphetamine, Karsono (2004) bahwa: l) jenis obat terlarang berbentuk pil, kapsul, dan tepung. 2) Jenis obat "pendorongan" stimulan yang dapat mengubah susunan hati. 3) Satu tipe amphetamin memiliki dampak perangsang yang kuat pada jaringan saraf. 4) Pengguna amphetamin dan methampetamin sering menjadi tergantung pada obat ini secara mental. 5) Pengguna sering bertingkah laku kasar dan aneh. 6) Dampak yang ditimbulkan oleh pengguna amphetamin, antara lain penurunan berat badan, gelisah, penampilan seperti kurang tidur, tekanan darah tinggi, denyut jantung tidak beraturan, paranoid yang mendalam, dan sering pingsan akibat kelelahan. 7) Amphetamin dikenal juga dengan sebutan "amphef Sedangkan methampetamin disebut ekstasi, speed, whizz, billywhizz, peppills, dan Jain-lain.

Amphetamine, banyak dipakai oleh para supir kendaraan umum; pelajar, dan mereka yang ingin tetap terjaga (melek) terus. Yang termasuk dalam golongan ini (Amphetamine), di antaranya adalah: ekstasi. Karsono (2004), menyatakan bahwa Ekstasi adalah: 1) Termasuk zat psikotropika dan diproduksi secara tidak sah (illegal) di dalam laboratorium dan dibuat dalam bentuk tablet atau kapsul. 2) Dapat mendorong fisik pengguna bekerja di luar batas kemampuan. Akibatnya cairan tubuh mengalami kekeringan., karena adanya pengerahan tenaga yang luar biasa. Beberapa pengguna ekstasi akhirnya meninggal dunia, karena terlalu banyak minum air akibat kehausan yang berlebihan. 3) Dampak yang ditimbulkan oleh pengguna ekstasi, antara lain: diare, rasa haus berlebihan, hiperaktif, sakit kepala dan pusing, menggigil yang tidak terkendali, detak jantung tidak beraturan dan cepat, mual disertai muntah-muntah atau 
hilangnya nafsu makan. 4) Ekstasi dikenal pula dengan sebutan inex, I, knding, dan lainlain. Lihat BNN, 2005, hal. 21. Dalam dosis yang moderat, amphetamine/ekstasi, meningkatkan kesiagaan; membuat badan senantiasa terasa bubar, tidak akan merasa lelah, juga tidak akan membuat mengantuk, melainkan menimbulkan kesegaran serta gairah kegembiraan yang luar biasa. Amphetamine atau ekstasi dikenal juga membuat seseorang menjadi tahan lapar, bahkan tidak merasa lapar; sehingga tidak jarang pula dipakai untuk menguruskan badan.

Metamphetamine, atau yang sering disebut shabu-shabu adalah kristalisasi dari bubuk/powder atau bahan obat-obat dari "turunan" amphetamine, yang memiliki khasiat atau "keampuhan" serta akibat yang tidak berbeda jauh dengan amphetamine, yang jelas pula berbahaya serta terlarang termasuk narkoba. Dan yang terkenal sebagai metamphetamine, di antaranya adalah: Shabu-shabu. Karsono (2004) dalam BNN (2005), menyatakan shabu-shabu adalah: 1) Shabu-shabu dikenal dengan sebutan ice (merhampetamine). 2) Berbentuk kristal dan tidak berbau serta tidak berwarna, karena itu mendapat sebutan ice. 3) Memiliki dampak yang sangat kuat pada jaringan saraf. 4) Penggunaan shabu-shabu akan menjadi ketagihan secara mental, jika digunakan cukup lama akan menyebabkan peradangan pada otot hati serta menyebabkan kematian. 5) Dampak yang ditimbulkan oleh pengguna shabu-shabu, antara lain: penurunan berat badan berlebihan, itnpotensi, seriawan yang parah, halusinasi, kerusakan hati dan ginjal, kerusakan jantung, stroke, dan diakhiri kematian. 6) Shabu-shabu selain dikenal dengan sebutan ice, juga dikenal dengan sebutan kristal, ubas, mecin, dan lain-lain.

\section{Kelompok Depresan}

Barbiturate, dalam bahasa Indonesia lazim disebut: Barbiturat, dan dalam bahasa medik sering disebut: Fenobarbita, adalah jenis depresan yang bisa memperlambat aktivitas sistem saraf parasimpatik, sehingga membuat orang yang mengkonsumsinya merasa tubuh atau suasana hati dan pikirannya menjadi sangat nyaman, terlebih bila ia mengantuk (teler), maka rasa sakit atau "derita" yang tengah mendera/menghimpitnya, menjadi berkurang, bahkan hilang sama sekali berganti dengan eforia.

Benzodiazepine, umumnya lebih dikenal dengan sebutan: pil BK, atau pil koplo, dan sering pula dipasarkan antara lain dengan merk dagang: Rohipnol, Megadon, Stesolid. Depresan sangat fatal jika dikombinasikan atau terkombinasi dengan alkohol. Kematian 
sering terjadi setelah seorang pecandu menghadiri pesta coktail atau arinum-minuman keras (beralkohol). Juga di saat-saat mengalami withdrawal atau solus zat (ketagihan/sakaw), merupakan saat yang paling berbahaya; di mana gejala ketagihan barbiturat atau benzodiazepine/pil BK/pil koplo itu lebih sulit untuk ditanggulangi/ditangani dari ketagihan heroin. Bila diamati dengan seksama, gejalanya sebenarnya sudah muncul 2 jam setelah pemakaian berakhir; dalam waktu 24 jam, ka timbul tremor. Tremor adalah gerakan-gerakan pada anggota bagian tubuh yang terjadi tanpa terkontrol/di luar kemauan; seperti tiba-tiba menggelar/bergemataran, yang disebabkan adanya ketegangan emosinal, kemudian disusul kejang-kejang lalu bisa pula terjadi koma, bila tidak segera di bawa ke rumah sakit aiau mendapatkan terapi/ pengobatan di rumah sakit yang tepat.

Halusinsadogen, di antara obat-obatan yang tergolong ke dalam jenis ini, yang paling populer, adalah LSD (Lysergic Acid Diethimide), karena terkuat efeknya dari halusinogen lain. Halusinogen, artinya adalah bahan atau obat yang bisa menimbulkan halusinasi; dan kekuatannya pada LSD, disebutkan seratus kali psilosibin, dan empat ribu kali meskalin, dua macam zat yang termasuk dalam golongan halusinogetik (yang memiliki sifat halusinogen). LSD, telah banyak dipakai oleh para hippies, terlebih di tahun 1960-an; LSD yang juga dikenal dengan sebutan acid, mempunyai efek yang berbeda pada setiap pemakainya. Bahkan berbeda pula pada satu pemakai di kesempatan yang berlainan.

Pada pengguna inhalan, yaitu sejenis bahan atau obat yang dihirup/dimasukkan ke dalam tubuh melalui hidung dan trakhea (saluran pernapasan yang utama), umumnya adalah anak-anak belasan tahun, karena zat atau obat tersebut umumnya ada/mudah didapatkan di mana-mana. Zat utama inhalan adalah cairan hidrokarbon, hidrokarbon: Bahan/senyawa kimia yang hanya mengandung unsur hidrogen (gas tidak berwarna, tidak berbau, juga tidak ada rasanya) dan karbon (zat arang) saja. yang mudah menguap (volatif) yang berasal dari minyak tanah dan gas alam, atau yang banyak digunakan di industry dan di rumah-rumah tangga seperti: cairan pembersih (karbol/lisol). Karsono (2004), menyatakan bahwa inhalen dengan cara dihirup, merupakan hal sering kita dengar. Namun bagaimana dampak yang ditimbulkan, simak penjelasan berikut ini: 1) Penyalahgunaan inhalen merupakan tindakan yang menyimpang dari seorang pengguna dengan memanfaatkan lem, tiner, cat dan zat yang sejenis dengan menghirup uapnya, 2) 
Penyalahgunaan inhalen dengan cara dihirup dapat mempengaruhi pertumbuhan dan perkembangan oto-oto, urat saraf organ tubuh yang dapat menimbulkan permasalahan sumsum tulang. 3) Dapat menimbulkan mati mendadak, hal ini dikarenakan denyut jantung mendadak menjadi cepat tidak beraturan. Akhirnya terjadi gagal jantung. 4) Dampak lain yang ditimbulkan penyalahgunaan inhalen, adalah hilang daya ingat, tidak mampu berpikir, mudah memar dan berdarah, kerusakan sistem safat pusat. Kerusakan hati, kerusakan jantung, sakit di sekitar perut, sakit ketika sedang buang air kecil, kram otot, dan batuk-batuk.5) Dikenal dengan sebutan "ngelem", karena kegiatan ini berkaitan dengan menghirup inhalen.

Zat Adiktif, salah satu jenis zat adiktif yang paling sering dikonsumsi masyarakat, tanpa diketahui efek-sampingnya yang bisa merusak atau membahayakan kesehatan tubuh/jiwa, adalah minuman beralkohol, seperti misalnya: a) Beer (bir), b) Wine (anggur), c) Whisky (wiski), dan d) Vodka (boles). Maupun minuman beralkohol buatan lokal seperti: a) Arak dan b) Tuak. Alkohol berpotensi menghalangi penyerapan gizi, sehingga pecandu akan mengalami kekurangan gizi; dan akibat dari pemakaian yang berlebihan, dapat menimbulkan komplikasi pada: hati, muntah darah, atau gagal fungsi hati, koma, bahkan bisa meninggal secara mendadak. Masih banyak lagi efek-efek negatif yang sering ditimbulkan akibat minum minuman keras, sehingga minuman yang tergolong beralkohol tinggi, atau yang kini disebut: Miras (minuman keras), dilarang dijual bebas di warung-warung atau toko-toko, pasar, maupun di pusat-pusat perbelanjaan seperti di mal dan pasar-pasar swalayan (super-market).

\section{Pencegahan Melalui Pemahaman Hukum Pidana Narkotika Terhadap Anak}

Sanksi Pidana Pelaku sebagai Peyalahguna Narkotika, Pelaku penyalahguna narkotika dapat dijerat dengan Pasal 127 Undang-Undang No. 35 Tahun 2009 tentang Narkotika (UU Narkotika). Sanksi yang dapat dijatuhkah adalah pidana pejara selama 1 sampai 5 tahun. Namun jika pelaku terbukti hanya sebagai korban penyalahgunaan narkotika, maka baginya menjalani rehabilitasi medis dan rehabilitasi sosial.

Sanksi Pidana Pelaku sebagai Kurir Perdagangan Narkotika, Mengenal Sanksi Hukum Kasus Narkotika yang Melibatkan Anak: Ancaman pidana bagi anak yang menjadi kurir narkotika adalah setengah dari ancaman pidana yang terdapat dalam UU Narkotika. https://www.hukumonline.com/berita/baca/lt57c262338 ae56/mengenal- 
sanksi-hukum-kasus-narkotika-yang-melibatkan-anak/, (diakses pada tanggal 2 Januari 2020). Bagi kurir perdagangan narkotika dapat dijerat tergantung pada jenis narkotika yang dibawanya. Misalnya: untuk perantara dalam transaksi narkotika golongan I berdasarkan Pasal 114 ayat (1) UU Narkotika, terhadap pelakunya dapat diancam dengan pidana penjara seumur hidup atau pidana penjara paling singkat 5 tahun dan denda paling sedikit satu miliar rupiah dan paling banyak sepuluh miliar rupiah. Atau dapat dijerat dengan ketentuan mengenai penguasaan narkotika yang diatur dalam Pasal 112 UU Narkotika dengan acaman pidana penjara 4 sampai 20 tahun atau pidana denda sebesar delapan ratus juta rupiah sampai dengan delapan miliar rupiah bahkan diambah $1 / 3$ dari delapan miliar rupiah tersebut. Dalam penguasaan narkotika, terdapat yuriprudensi Putusan Pengadilan Tinggi Sumatera Barat, bahwa Bezit dalam perkara narkotika harus memenuhi dua unsur, yakni kekuasaan atas suatu benda dan adanya kemauan untuk memiliki benda itu. Artinya, bila seseorang tidak mengetahui bagaimana ia sampai membawa narkotika dan tidak menghendaki untuk memiliki benda itu, maka unsur pembuktian dalam Pasal 112 UU Narkotika menjadi tidak terpenuhi.

Terkait pelaku yang melibatkan anak-anak sebagai kurir perdagangan narkotika juga dapat dijerat dengan Pasal 133 ayat (1) UU Narkotika. Bagi pelaku yang menyuruh dengan memberi atau menjanjikan sesuatu, atau dengan cara memaksa dengan ancaman dan kekerasan, atau melakukan tipu muslihat terhadap si anak, maka pelaku dapat dipidana dengan pidana mati atau pidana penjara seumur hidup, atau pidana penjara paling singkat 5 tahun dan paling lama 20 tahun dan pidana denda paling sedikit $d u a$ miliar rupiah dan paling banyak dua puluh miliar rupiah.

Penegakan Hukum bagi Anak sebagai Pelaku Tindak Pidana Narkotika, mengenal Sanksi Hukum Kasus Narkotika yang Melibatkan Anak: Ancaman pidana bagi anak yang menjadi kurir narkotika adalah setengah dari ancaman pidana yang terdapat dalam UU Narkotika. https://www.hukumonline.com/berita/baca/lt57c262338 ae56/mengenalsanksi-hukum-kasus-narkotika-yang-melibatkan-anak/. (diakses pada tanggal 2 Januari 2020). Anak juga dapat dijerat dengan UU Narkotika, namun terdapat pengecualian menurut hukum. Untuk diketahui, ancaman pidana penjara yang dapat dijatuhkan kepada anak paling lama setengah dari maksimum ancaman pidana penjara bagi orang 
dewasa. Artinya, ancaman pidana bagi anak yang menjadi kurir narkotika adalah setengah dari ancaman pidana yang terdapat dalam UU Narkotika.

Terhadap anak-anak yang terjerat tindak pidana narkotika, penegakan hukumnya harus didasarkan pada mekanisme yang diatur dalam Undang-Undang No. 35 Tahun 2014 tentang Perubahan atas Undang-Undang No. 23 Tahun 2002 tentang Sistem Peradilan Anak (UU Perlindungan Anak). Penegakan hukum bagi pelaku yang masih berusia di bawah, terdapat ketentuan khusus yang dinamakan dengan diversi, yakni pengalihan penyelesaian perkara anak dari proses peradilan pidana ke proses di luar peradilan pidana. Namun diversi hanya dapat dilakukan dengan syarat,yakni dalam hal tindak pidana yang dilakukan diancam dengan pidana penjara di bawah 7 tahun dan perbuatan yang dilakukan si anak bukan merupakan pengulangan tindak pidana.

Menurut Undang-Undang No. 11 Tahun 2012 tentang Sistem Peradilan Pidana Anak (UU SPPA), upaya diversi dilakukan untuk menghindari dan menjauhkan anak dari proses peradilan sehingga dapat menghindari stigmatisasi terhadap anak yang berhadapan dengan hukum dan diharapkan anak dapat kembali ke dalam lingkungan sosial secara wajar. Proses diversi dilakukan dengan melalui musyawarah yang melibatkan anak dan orang tua/walinya, pembimbing kemasyarakatan, dan pekerja sosial profesional, yang dilakukan dengan pendekatan keadilan restoratif.

Pasal 3 UU SPPA juga mengatur mengenai hak bagi anak-anak yang diproses secara hukum melalui peradilan pidana, diantaranya: diperlakukan secara manusiawi dengan memperhatikan kebutuhan sesuai dengan umurnya; dipisahkan dari orang dewasa; tidak dijatuhi pidana mati atau pidana seumur hidup; tidak ditangkap, ditahan, atau dipenjara, kecuali sebagai upaya terakhir dan dalam waktu yang paling singkat; memperoleh keadilan di muka pengadilan anak yang objektif, tidak memihak, dan dalam sidang yang tertutup untuk umum; tidak dipublikasikan identitasnya; memperoleh pendidikan; dan hak-hak lain sesuai dengan ketentuan peraturan perundang-undangan.

\section{Pencegahan Melalui Pemahaman Non Hukum Pidana Narkotika Pada Anak}

Berbicara tentang pencegahan agar tindak pidana pada anak tidak terjadi, tentunya dengan mengadakan pendidikan hukum terkait ancaman sanksi pidana bagi semua pemangku kepentingan (stake holder) yang bertanggungjawab terhadap anak di 
Indonesia sangat penting dilakukan. Lingkungan, terutama keluarga menjadi kunci utamanya.

Tips Mencegah Anak Menjadi Penyalahguna Narkotika, Pertama, membangun komunukasi pada anak dengan cara: mendengarkan secara aktif, menghargai perasaannya, menghormati hak pribadinya, menggunakan kata "saya" lebih baik daripada 'kamu", tetaplah pada subjek pembicaraan. Kedua, pemberian cinta dan kasih sayang kepada anak ditunjukkan secara wajar sejak kecil supaya anak dapat merasakan bahwa ia disayangi, disenangi, diperhatikan, diterima dan dihargai. Ketiga, secara spiritual dilakukan dengan tahapan: menanamkan keharaman narkotika, menanamkan kehidupan beragama di lingkungan keluarga dan sekolah, meningkatkan keimanan dan ketaqwaan kepada Tuhan dalam setiap aktifitas, taat beribadah, dan bersyukur atas pemberian Tuhan. Keempat, pemupukan kepercayaan diri, dengan cara: Berfokus pada kelebihan dan kemampuan anak, bukan pada kesalahan atau kekurangannya. Berfokus pada usahanya, bukan hasilnya. Menahan diri untuk tidak mengkritik, menghina, mengejek dan mempersalahkan, yang semuanya ini adalah bentuk penolakan. Memberi pengalaman yang membesarkan hati. Pemberian tugas dan tanggung jawab yang membangun kepercayaan diri (Direktorat Diseminasi Informasi, Deputi Bidang Pencegahan Badan Narkotika Nasional Republik Indonesia Jakarta, 2012.).

Tips Mencegah Anak Menjadi Kurir Perdagangan Narkotika, Pertama, selektif dalam bergaul. Kedua, jangan mudah percaya dengan tawaran gaji besar melalui kenalan di media sosial. Ketiga, fokus pada hal-hal yang positif, dengan cara mengisi waktu dengan rutinitas dan kesibukan yang bermanfaat. Keempat, Jangan takut kehilangan teman yang berperilaku negatif. Kelima, bentengi diri dengan menjaga keimanan dan berpegang kepada ajaran agama. Keenam, periksa barang titipan dari teman atau orang lain di hadapannya dan jangan mau dititipi barang atau tas yang tidak diketahui isinya. Ketujuh, selesaikan masalah dengan bantuan orang yang tepat, baik masalah ekonomi (finansial) maupun permasalahan pribadi. Kedelapan, selalu menjaga keterbukaan dan hubungan yang baik di tengah-tengah keluarga (Supartini, 2019).

\section{SIMPULAN}

Tindak pidana narkotika dapat mejerat anak sebagai pelakunya, baik itu penyalahguna maupun kurir. Meskipun terdapat pengecualian dalam penegakan 
hukumnya (law enforcement), sanksi pidana penjara maupun denda yang mengintai anak sebagai pelaku tetap dipandang tidak main-main beratnya. Lingkungan menjadi tolak ukur dalam pencegahan tindak pidana narkotika pada anak, untuk itu pendidikan hukum sangat urgen dilakukan guna penguatan kesadaran hukum dalam masyarakat agar anakanak yang notabene merupakan generasi penerus dan masa depan bangsa dapat terhindar dari tindak pidana narkotika.

\section{DAFTAR PUSTAKA}

Badan Narkotika Nasional Republik Indonesia. (2005). Buku Panduan Pencegahan Penyalahgunaan Narkoba Sejak Dini. Jakarta: Direktorat Diseminasi Informasi, Deputi Bidang Pencegahan Badan Narkotika Nasional Republik Indonesia.

Buku Panduan Pencegahan Penyalahgunaan Narkoba Sejak Dini, Dicetak oleh Direktorat Diseminasi Informasi, Deputi Bidang Pencegahan Badan Narkotika Nasional Republik Indonesia Jakarta, pada tahun 2012

Eleanora, F.N. (2017). Bahaya Penyalahgunaan Narkoba serta Usaha Pencegahan dan Penanggulangannya (Suatu Tinjauan Teoritis), Jurnal Hukum, Vol XXV, No. 1, April 2017).

Hukum Online. Mengenal Sanksi Hukum Kasus Narkotika yang Melibatkan Anak: Ancaman pidana bagi anak yang menjadi kurir narkotika adalah setengah dari ancaman pidana yang terdapat dalam UU Narkotika. https://www.hukumonline.com/berita/baca /lt57c262338 ae56/mengenal-sanksihukum-kasus-narkotika-yang-melibatkan-anak/

Indrawan, (2001). Kiat Ampuh Menangkal Narkoba, Bandung: Pionir Jaya,

Indrawan. (2001). Kiat Ampuh Menangkal Narkoba. Bandung: Pionir Jaya.

Kusno, A. (2009). Kebijakan Kriminal dalam Penanggulangan Tindak Pidana Narkotika oleh Anak, (Malang: UMM Press,

Makarao, (2003), Tindak Pidana Narkotika, Jakarta: Ghalia Indonesia

Nainggolan, M., Elvi Z., dan Saparuddin, (2010), Peranan Hakim dalam Memberikan Perlindungan Hukum terhadap Anak Korban Penyalahgunaan Narkotika (Studi Pengadilan Negeri Lubuk Pakam), Mercatoria, 3 (2): 116-132

O.C. Kaligis \& Associates. (2002). Narkoba dan Peradilannya di Indonesia, Reformasi Hukum Pidana Metaidi Perundangan dan Peradilan. Bandung: Alumni.

Ratna, (2017) WP, Aspek Pidana Penyalahgunaan Narkotika: Rehabilitasi Versus Penjara, (Jakarta: Legality

Silalahi, D.H. (2018). Penanggulangan Tindak Pidana Penyalahgunaan Narkotika di SAT RES Narkoba Polres Tebing Tinggi, Jurnal Ilmiah Penegakan Hukum5, (2): 60- 67.

Sirait, E.W. \& Rafiqi (2018). Pertimbangan Hakim dalam Menjatuhkan Putusan Tindak Pidana Narkotika Yang Dilakukan Pengedar pada Putusan No : 2071/Pid.Sus/2016/Pn-Mdn), 5 (1) 2018: 1-7.

Soedarto. (1981). Kapita Selekta Hukum Pidana. Bandung: Alumni,

Soedjono, A. (2000), Patologi Sosial. Bandung: Alumni.

Sunarso. S. (2004), Penegakan Hukum dalam Kajian sosiologis, Jakarta: Raja Grafindo Persada,

Supartini, L. (2019). Panduan Keimigrasian: Tips Agar Tidak Terjebak Menjadi Kurir Narkoba, Tips https://buruhmigran.or.id /2019/12/09/tips-agar-tidak-terjebak-menjadi-kurir-narkoba/. (diakses pada tanggal 2 Januari 202)

Undang-Undang Republik Indonesia No. 35 Tahun 2009 tentang Narkotika.

Undang-Undang Republik Indonesia No. 35 Tahun 2009 tentang Narkotika. 